\title{
Anti-proliferative and apoptotic effects of hull-less pumpkin extract on human papillary thyroid carcinoma cell line
}

\author{
Mohammad Hadi Bahadori ${ }^{1}$, Zoleikha Azari ${ }^{1}$, Arash Zaminy ${ }^{1}$, Sara Dabirian ${ }^{2}$, Seyed Mojtaba Mehrdad ${ }^{3}$, \\ Bahman Jalali Kondori ${ }^{4,5}$ \\ ${ }^{1}$ Cellular and Molecular Research Center, Faculty of Medicine, Guilan University of Medical Sciences, Rasht, ${ }^{2}$ Department of Pharmaceutical \\ Biotechnology, School of Pharmacy, Guilan University of Medical Sciences, Rasht, ${ }^{3}$ Department of Endocrinology, Guilan University of Medical \\ Sciences, Rasht, ${ }^{4}$ Department of Anatomical Sciences, Faculty of Medicine, Baqiyatallah University of Medical Sciences, Tehran, ${ }^{5}$ Baqiyatallah Research \\ Center for Gastroenterology and Liver Diseases (BRCGL), Baqiyatallah University of Medical Sciences, Tehran, Iran
}

Abstract: Papillary thyroid carcinoma (PTC) is one of the most common cancers of the endocrine system. Previous studies have shown that the extract of hull-less pumpkin seed (HLPS) has a significant anti-cancer effect. The aim of this study was to evaluate the effect of this plant extract on the proliferation of PTC cells. In this study, an extract of this plant was prepared by soxhlet extraction method and analyzed by Gas Chromatography-Mass Spectrometry. The cytotoxicity of PTX and plant extract was investigated using the methylthiazol tetrazolium (MTT) method. For careful investigation of morphological alteration, we used hematoxylin and eosin and Giemsa stinging. Based on MTT assay test, the $\mathrm{IC}_{50}$ value of paclitaxel (PTX) was significantly less than the hydro-alcoholic extract of HLPS at all of the incubation time. Our results of histological staining showed that HLPS and PTX induced significant morphological alteration in the PTC cultured cell that consistent with cell death. Comparing the groups treated by PTX or HLPS with control group showed significant differences. It seems that HLPS extract has an apparent effect on treatment of PTC, at least in laboratory condition, albeit for realistic decision about the effect of HLPS on PTC, more molecular investigations are necessary.

Key words: Thyroid neoplasms, Paclitaxel, Cell proliferation, Herbal medicine

Received August 26, 2020; 1st Revised October 20, 2020; 2nd Revised November 30, 2020; Accepted December 14, 2020

\section{Introduction}

The occurrence of thyroid cancer has increased 3-fold high survival statistics when treated suitably. Based on the predominantly follicular growth pattern, papillary thyroid carcinomas (PTCs) include several subtypes. The present treatments of PTC encompass surgery, hormone therapy

\section{Corresponding author:}

Bahman Jalali Kondori (iD

Department of Anatomical Sciences, Faculty of Medicine, Baqiyatallah University of Medical Sciences, Tehran 009821, Iran

E-mail: Bahmanjalali2010@gmail.com over the past decades and the prevalence of different genetically profiles have altered over time [1]. Except medullary thyroid carcinoma, all thyroid malignancies are derived from thyroid follicular cells [2]. Among of all malignancies of thyroid gland, $80 \%$ are PTCs [3].

Paclitaxel (PTX) is one of the chemotherapy drugs that used to treat a number of cancer types. Aforementioned drug was first isolated in 1971 from the Pacific yew and permitted for medical usage 22 years later in 1993. Today PTX is on the World Health Organization's List of Essential Medicines [4]. Because of adverse side effects of chemotherapeutic drugs in patients and invoke drug resistance, single targeted aforementioned medications commonly lack efficacy. In the recent years, traditional herbal drugs play a key role in treating some 
type of cancers, in a holistic and systematic manner $[5,6]$. Understanding the fundamental basis of traditional herbal medicine and its bioactive chemical ingredients may help us to modernization of herbal medications and the discovery of novel agents for cancer therapy management. Today, some surveys point to the increasing usage of herbal medications or their isolated constituents as complementary agents of chemotherapeutic drugs in cancer subjects to alleviate clinical symptoms or improve quality of life.

Various products of pumpkin are one of the aforementioned drugs that have been frequently used as useful food in traditional medicine. Pumpkin is one member of the Cucubitaceae family. Telfairiaoccidentalis Hook, C. Pepo, Cucurbita moschata, C. Maxima, C. Mixta, and C. Ficifolia are other members of this family $[7,8]$. So far, several experimental and clinical studies showed anticancer activity of pumpkin extract and various fractions of it against breast carcinoma, prostate cancer, melanoma and leukemia [9-12]. Some surveyed proposed the crucial role of Moschatin, an rRNA Nglycosidase from pumpkin seeds, in blocking of protein synthesis in the rabbit reticulocyte [13]. It was reported that pumpkin extracts significantly reduced tumor weight in S180-bearing mice. A more recent investigation performed by Richter et al. [14] emphasized the role of pumpkin seed in breast cancer prevention and treatment.

Knowing the powerful antioxidant properties of hull less seed of Pumpkin and its proven role in prevention of some cancers, present survey aimed to analyze the therapeutic effects of hydro-alcoholic extract of hull-less pumpkin seed (HLPS) on human PTC cell line by investigate consequence morphological alterations and a comparison with PTX was performed.

\section{Materials and Methods}

\section{Extract preparation}

Hull less seed pumpkin was purchased from VBG Company (Rasht, Iran). For preparation of extract, $50 \mathrm{gr}$ of grinded HLPS was soaked in $500 \mathrm{cc}$ of ethanol (80\%v/v) for 3 days. The prepared suspension was filtered by using filter paper and concentrated by rotary vacuum evaporator at $40^{\circ} \mathrm{C}$. Some concentrations of the extracts $(1,20,50,100,200,800$, $1,600,2,400,2,800$, and $6,400 \mu \mathrm{g} / \mathrm{ml}$ ) were prepared with phosphate buffer $(\mathrm{pH}=7.4)$ and sterilization of prepared extracts was performed. The ethanolic extract of hull less seed pumpkin was analyzed by Gas Chromatography-Mass Spec- trometry (GC-MS). In the present study, PTX was purchased from Sigma-Aldrich Company (St. Louis, MO, USA).

\section{Cell culture}

The PTC cell line was purchased from the Iran-Pasteur Institute (Tehran, Iran). Papillary thyroid carcinoma cells were cultured in Dulbecco's modified Eagle medium (DMEM, Sigma-Aldrich) supplemented with 1\% penicillin-streptomycin (Sigma-Aldrich) and 10\% fetal bovine serum (FBS, Sigma-Aldrich), incubated at $37^{\circ} \mathrm{C}$ and in humidified atmosphere containing 5\% $\mathrm{CO}_{2}$. PTC cells were passaged for appropriate proliferation. The PTC cells were digested with $0.25 \%$ trypsin solution and $0.02 \%$ EDTA, and propagated when the cell density reached $80 \%$.

\section{Methylthiazol tetrazolium assay}

For determine the cytotoxic effect of PTX and HLPS hydro-alcoholic extract on cultured PTC cell line, methylthiazol tetrazolium (MTT) assay was performed 24, 48, and 72 hours after incubation of cells with different concentrations of PTX or HLPS. PTC cultured cells were seeded in 96-well plates with a concentration of $5 \times 10^{3}$ cells per a well and then incubated for 24 hours at $37^{\circ} \mathrm{C}$ and in a humidified atmosphere containing $5 \% \mathrm{CO}_{2}$. Non-adherent cells were removed and then cells were treated with different concentrations of either PTX (ranging from 0/00001 to $6,000 \mu \mathrm{g} / \mathrm{ml}$ ) and or HLPS (ranging from $1-6,400 \mu \mathrm{g} / \mathrm{ml}$ ) followed by further incubation for 24, 48, and 72 hours in the aforementioned situation. After each mentioned incubation time, cells were washed twice with PBS, and $90 \mu \mathrm{l}$ of fresh medium and 10 $\mu$ l of MTT (Sigma, Germany) solution ( $5 \mathrm{mg} / \mathrm{ml}$ in PBS) was added to each well, followed by incubation for an additional 4 hours. The supernatants were removed and $100 \mu \mathrm{l}$ isopropanol alcohol was added to each well. After complete dissolution of formazan crystals, the optical density of the solution was measured by a microplate spectrophotometer at 490 $\mathrm{nm}$ using a reference wavelength of $630 \mathrm{~nm}$. The percentage of cell viability was determined based on following equation: (OD treated group/OD control group) $\times 100$. Experiments were performed three times in triplicate. Nonlinear regression (curve fit) was used to determine the half maximal inhibitory concentration $\left(\mathrm{IC}_{50}\right)$ and its $95 \%$ confidence interval. $\mathrm{IC}_{50}$ value was determined by use of GraphPad Prism software (version 5, GraphPad Software, USA). 


\section{Hematoxylin and eosin staining}

An additional test for evaluating cell morphology after being treated by either PTX or HLPS extract was H\&E staining. For H\&E staining, PTC cells were seeded in 96-well plates at a density of $5 \times 10^{3}$ cells per a well and incubated for 24 hours and then treated with different concentrations of either PTX $(0 / 00001-6,000 \mu \mathrm{g} / \mathrm{ml})$ or herbal extract $(1-6,400 \mu \mathrm{g} / \mathrm{ml})$ for 24,48 , and 72 hours. PTC cells were fixed by paraformaldehyde $4 \%$ and stained with hematoxylin and eosin dye (Biosynthesis Biotechnology Co., Ltd., Beijing, China) followed by the manufacturer's instructions. After staining process, the stained cells were detected under optical microscope (Changfang Optical Instruments, Shanghai, China).

\section{Giemsa staining}

Giemsa staining was performed to investigate the morphology of cells. For this purpose, PTC cultured cells were seeded in 96-well plates at a density of $5 \times 10^{3}$ cells per well and incubated for 24 hours. Cells were then treated with different concentrations of PTX $(0 / 00001-6,000 \mu \mathrm{g} / \mathrm{ml})$ or HLPS extract $(1-6,400 \mu \mathrm{g} / \mathrm{ml})$ for 24,48 , and 72 hours. PTC cells were fixed and stained by Giemsa dye (Sigma-Aldrich) protocol albeit with minor modification. The stained cells were observed under microscope (Changfang Optical Instruments).

\section{Statistical analysis}

The obtained data are expressed as the mean \pm standard error and as absolute values. Continuous data with a normal distribution were analyzed using a $t$-test and one-way ANOVA followed by Tukey's test. Statistical analyses were performed using SPSS Statistics for Windows, Version 15.0 (SPSS Inc., Chicago, IL, USA). A $P<0.05$ was accepted as statistically significant.

\section{Results}

\section{GC-MS analysis}

The results pertaining to GC-MS analysis of the ethanolic extract of hull less seed pumpkinlead to the identification of a number of compounds. These compounds were identified through mass spectrometry attached with GC. The chromatogram of hull less seed pumpkin extract is shown in Fig. 1.

According to the results of the GC mass, 9 12-octadecadienoic acid ethyl esters (Oleic Acid): 16.21\%, Stigmasta-7,25-

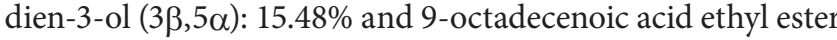
(Linoleic acid): $10.04 \%$ were the most common compounds in the extract of hull less seed pumpkin.

\section{HLPS extract and PTX showed cytotoxic effect on PTC cell line}

The MTT assay was performed to determine the cytotoxic effects of different concentrations of PTX or pumpkin hydroalcoholic extract on PTC cells. The results of MTT test showed that HLPS and PTX inhibit the proliferation of PTC cells in laboratory condition. The inhibition of PTC cell proliferation

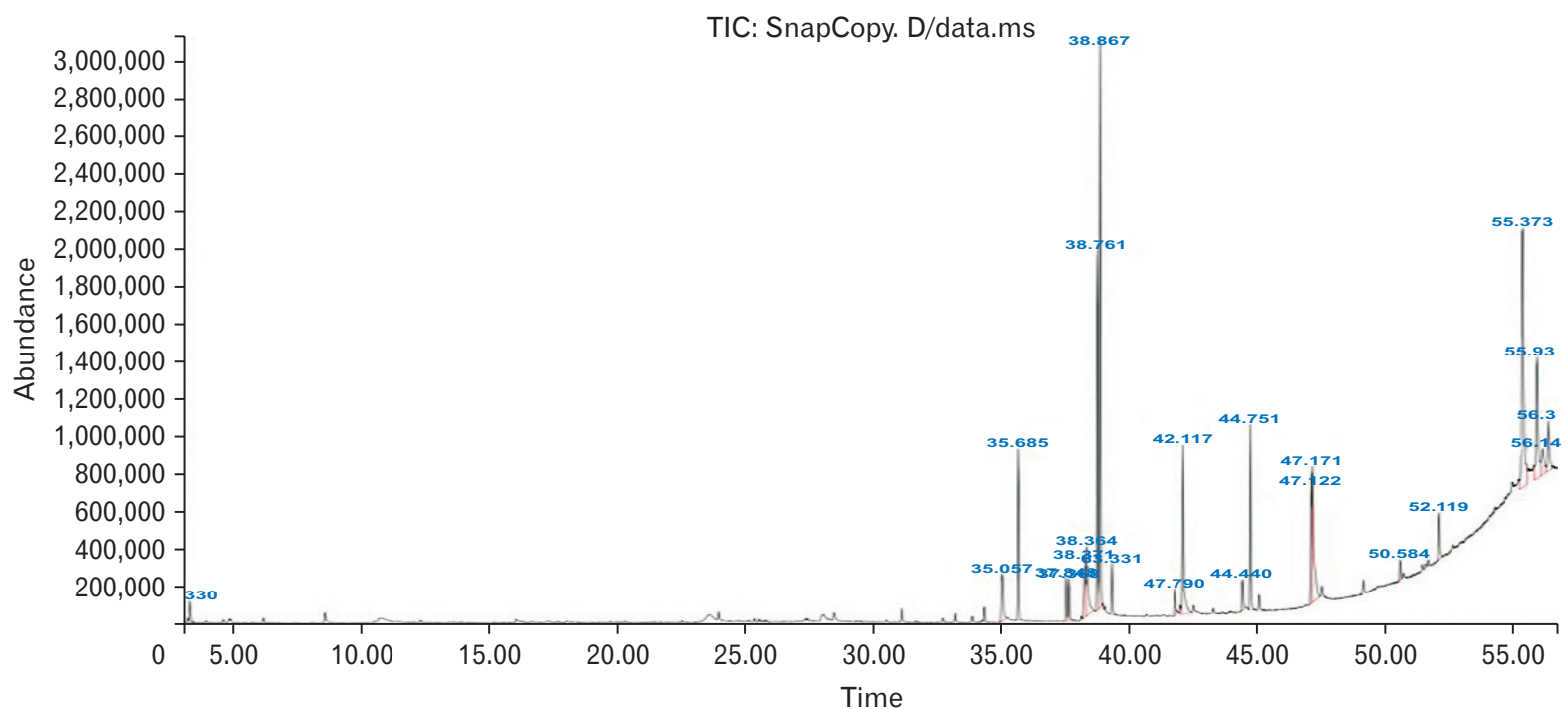

Fig. 1. Chromatogram of hull less seed pumpkin extract. Most common compounds in the extract is 9,12-octadecadienoic acid ethyl esters (Oleic Acid): $16.21 \%$. 

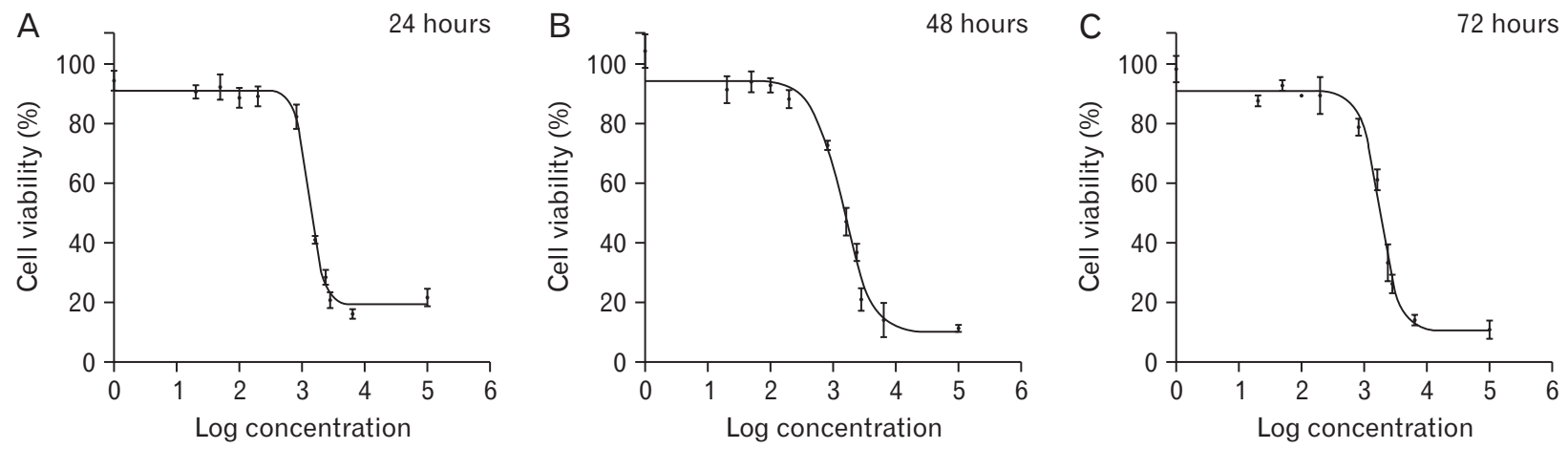

Fig. 2. The MTT assay results of treated cells by hydro-alcoholic extract of HLPS for 24 (A), 48 (B), and 72 (C) hours. In the dose of 1,20 , 50,100 , and $200 \mu \mathrm{g} / \mathrm{ml}$ the inhibition of PTC cell proliferation was $5 \%$ to $15 \%$ and in the dose of $800 \mu \mathrm{g} / \mathrm{ml}$ was nearly $30 \%$. HLPS, hull-less pumpkin seed; MTT, methylthiazol tetrazolium; PTC, paclitaxel.
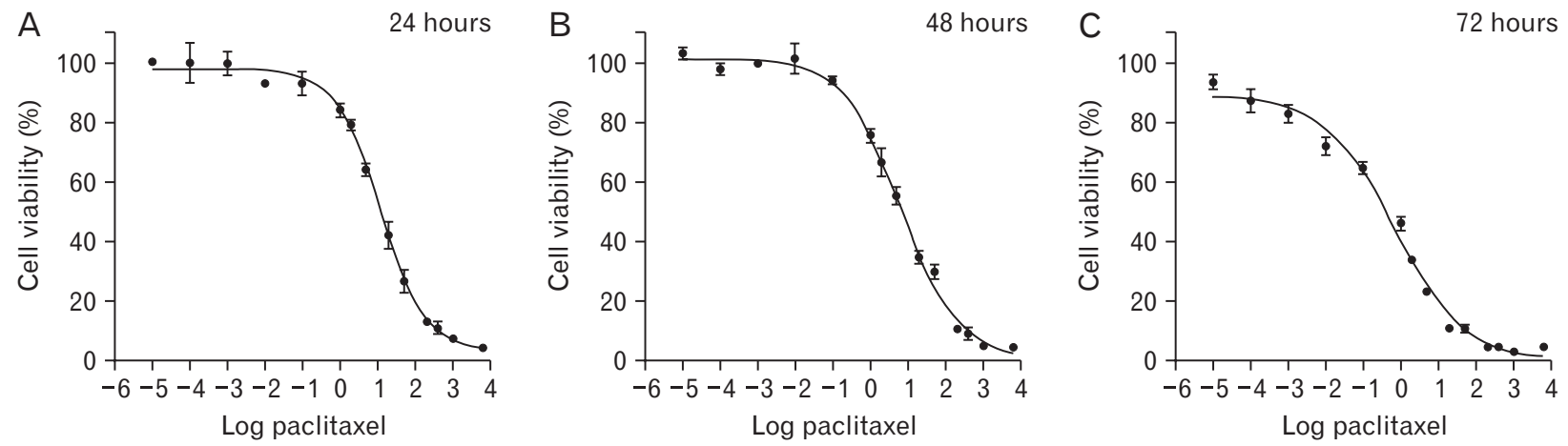

Fig. 3. The MTT assay results of PTX treated cells. The results show that this drug in the dose of $0.001,0.0001$, and $0.00001 \mu \mathrm{g} / \mathrm{ml}$ after 24 (A) and 48 (B) hours don't inhibit cell proliferation. Also, in the dose of 0.01 and $0.1 \mu \mathrm{g} / \mathrm{ml}$, PTX don't effects on PTC cell proliferation significantly $(P>0.05)$. in the dose of $0.1 \mu \mathrm{g} / \mathrm{ml}$ after 72 hours $(C)$ the inhibition of cell proliferation was nearly $30 \%$. MTT, methylthiazol tetrazolium; PTC, papillary thyroid carcinoma; PTX, paclitaxel.

in the dose of $1,20,50,100$, and $200 \mu \mathrm{g} / \mathrm{ml}$ of HLPS hydroalcoholic extract was $5 \%$ to $15 \%$ and in the dose of $800 \mu \mathrm{g} / \mathrm{ml}$ was nearly $30 \%$. By doubling of HLPS dose $(1,600 \mu \mathrm{g} / \mathrm{ml})$, the inhibition of cell proliferation also doubled (nearly $30 \%)$. The dose of 2,400, 2,800, and 6,400 of HLPS induced cell proliferation arrest between $70 \%$ to $90 \%(P<0.05)$. The Fig. 1 present the results of various doses of HLPS extract on percentage of cell viability in 24,48 , and 72 hours of drug treatment (Fig. 2).

The results of MTT assay in the treated group with PTX showed that this drug in the dose of $0.001,0.0001$, and $0.00001 \mu \mathrm{g} / \mathrm{ml}$ after 24 and 48 hours don't inhibit cell proliferation. Also, in the dose of 0.01 and $0.1 \mu \mathrm{g} / \mathrm{ml}$, PTX don't affects on PTC cell proliferation significantly $(P>0.05)$. As the incubation time has increased, cell growth also increased, so that, in the dose of $0.1 \mu \mathrm{g} / \mathrm{ml}$ after 72 hours the inhibition of cell proliferation was nearly $30 \%$. After 72 hours, in the dose of $1,2,5,20$, and $50 \mu \mathrm{g} / \mathrm{ml}$ of PTX, cell proliferation was between $60 \%$ to $90 \%(P<0.05)$ (Fig. 3$)$.
Table 1. The results of $\mathrm{IC}_{50}$ values of PTX and HLPS extract on PTC cultured cells

\begin{tabular}{cccc}
\hline Compound & \multicolumn{1}{c}{$24 \mathrm{hr}$} & \multicolumn{1}{c}{$48 \mathrm{hr}$} & \multicolumn{1}{c}{$72 \mathrm{hr}$} \\
\hline HLPS $(\mu \mathrm{g} / \mathrm{ml})$ & $1,312 \pm 23.76$ & $1,379 \pm 307.42$ & $1,782 \pm 80.52$ \\
PTX $(\mu \mathrm{g} / \mathrm{ml})$ & $1,160 \pm 4.65$ & $6.831 \pm 0.81$ & $0.670 \pm 0.17$ \\
\hline
\end{tabular}

Values are presented as $\mathrm{IC}_{50} \pm \mathrm{SD}$. The present result showed that the $\mathrm{IC}_{50}$ value of paclitaxel was significantly less than extract of hull less seed pumpkin at all of the incubation times. PTX, paclitaxel; HLPS, hull-less pumpkin seed; PTC, papillary thyroid carcinoma.

Based on the results of MTT assay, amount of $\mathrm{IC}_{50}$ (half maximal inhibitory concentration) value of hydro-alcoholic extract of HLPS and PTX was calculated. The lower $\mathrm{IC}_{50}$ represents the higher potency of a compound to inhibit the growth of cells and to cause toxicity and cell death. Our result showed that the $\mathrm{IC}_{50}$ value of PTX was significantly less than the $\mathrm{IC}_{50}$ value of hydro-alcoholic extract of HLPS at all of the incubation time $(P<0.05)$. Table 1 summarizes the results of $\mathrm{IC}_{50}$ values of PTX and HLPS extract on PTC cul- 
tured cells.

\section{PTC cells of control group (without any intervention) presented the typical morphology of cancerous cells}

The cultured PTC cells that don't treat with HLPS or PTX showed some features such as: multidimensional appearance accompanied by stretched process, alteration in size and shape of nucleus and enlarged nucleolus. Aforementioned characteristics were consistent with the typical cancerous cells. Moreover, the plasma membrane of the cells was completely normal without any wrinkling.

HLPS hydro-alcoholic extract in the dose of $1,20,50,100$, and $200 \mu \mathrm{g} / \mathrm{ml}$ don't induce any morphological changes in PTC cells. HLPS in the dose of $800 \mu \mathrm{g} / \mathrm{ml}$ induced significant alteration in the morphology of PTC cells.

\section{H\&E and Giemsa staining showed morphological alterations in PTC cultured cells after treatment with different dose of HLPS and PTX}

In the present study, for careful investigation of morphological alteration, we used H\&E and Giemsa stinging. The results of Giemsa and H\&E staining showed that morphological changes such as nuclear shrinkage, chromatin condensa-
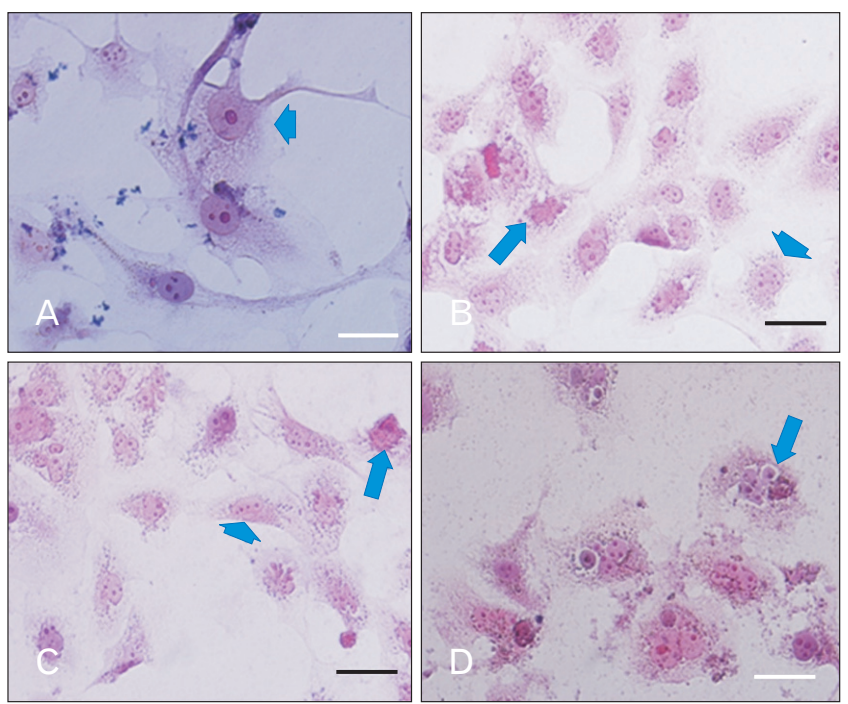

Fig. 4. H\&E staining of PTC cells. Control group without any treatment (A). PTC cells under treatment with HLPS with the dose of $800 \mu \mathrm{g} / \mathrm{ml}(\mathrm{B})$, and $1,600 \mu \mathrm{g} / \mathrm{ml}$ (C). PTC cells under treatment with PTX with the dose of $1 \mu \mathrm{g} / \mathrm{ml}$ (D); Chromatin condensation was occurred after cell treatment with different doses of PTX or HLPS hydro-alcoholic extract. The arrow heads indicate normal cells and the arrows indicate chromatin condensation and cell death. HLPS, hull-less pumpkin seed; PTC, papillary thyroid carcinoma; PTX, paclitaxel. Scale bar $=10 \mu \mathrm{m}$. tion and cytoplasmic membrane blabbing were occurred after cell treatment with different dose of PTX or HLPS hydroalcoholic extract, representing formation of apoptotic bodies in treated cell population, as compared to control (untreated PTC cells) which is shown no morphological changes.

HLPS in the dose of 100 and $200 \mu \mathrm{g} / \mathrm{ml}$ don't induce any morphological alterations in PTC cells nut; in the dose of $800 \mu \mathrm{g} / \mathrm{ml}$ prompted significant changes in the morphology of PTC cultured cells. The number of cancerous cells (typical PTC cells) in the dose of 1,600, 2,400, and 2,800 $\mu \mathrm{g} / \mathrm{ml}$ decreased sharply and the number of dead and floating cells increased significantly. This microscopic observation indicates that by increasing the HLPS dose and treatment duration, PTC cells complete apoptosis.

PTX in different dose induced morphological alteration in cultured PTC cells. This drug in the dose of $0.001,0.0001$, and $0.00001 \mu \mathrm{g} / \mathrm{ml}$ after 24 and 48 hours don't induce cell death but after 72 hours some significant alterations were showed that consistent with apoptosis progression. In the dose of $0.01,0.1,1,2,5,20$, and $50 \mu \mathrm{g} / \mathrm{ml}$, the number of dead cells increased. Fig. 4 and Fig. 5 represent some PTC morphological changes after treatment with HLPS and PTX. Also, in Fig. 6 percentages of dead PTC cells treated by extract and PTX at the 24, 48, and 72 hrs have been compared.

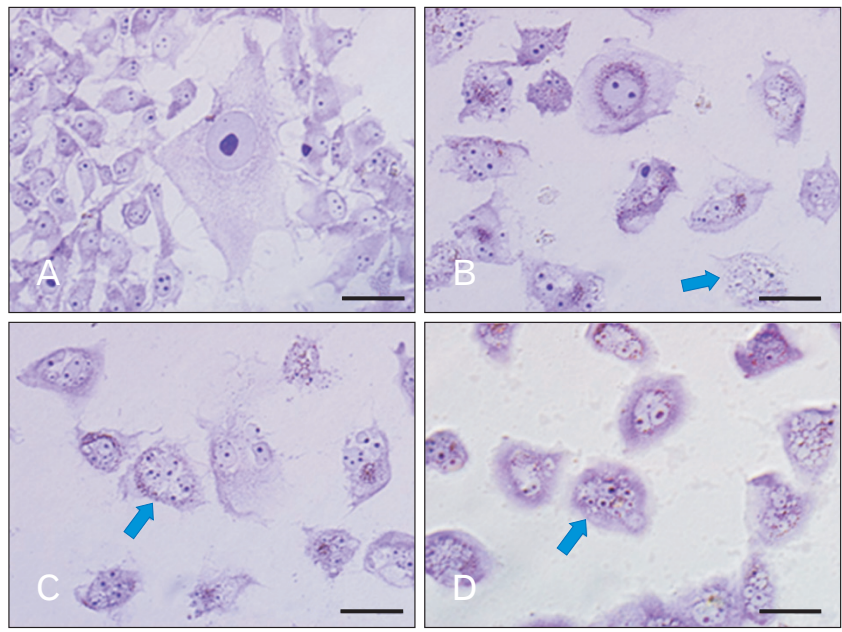

Fig. 5. Giemsa staining; untreated PTC cells (A), PTC cells treated by HLPS extract $(800 \mu \mathrm{g} / \mathrm{ml})(\mathrm{B})$, and $1,600 \mu \mathrm{g} / \mathrm{ml}(\mathrm{C})$ after 24 hours. PTC cells treated with PTX $(1 \mu \mathrm{g} / \mathrm{ml})$, after 24 hourrs (D). Nuclear fragmentation and cell death were occurred after cell treatment with different doses of PTX or HLPS hydro-alcoholic extract (arrows). HLPS, hull-less pumpkin seed; PTC, papillary thyroid carcinoma; PTX, paclitaxel. Scale bar $=10 \mu \mathrm{m}$. 

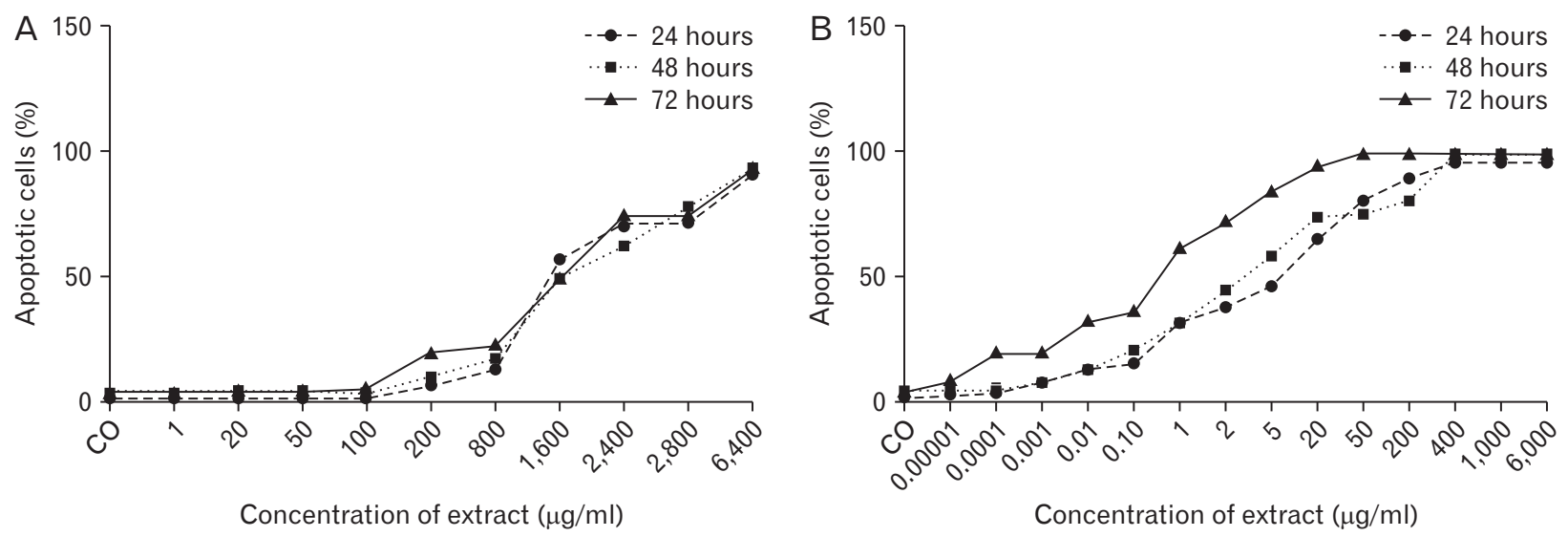

Fig. 6. Compare the percentage of dead cells in PTC cells treated with extract and PTX at the 24, 48, and 72 hours. PTC, papillary thyroid carcinoma; PTX, paclitaxel.

\section{Discussion}

In the present study, we investigate the anti-cancer effects of HLPS on PTC cell line in laboratory conditions. Some previous studies indicated the antioxidant activity of pumpkin and various fractions that obtained from it [7]. Pumpkin seeds are a rich source of alpha- tocopherol, as a powerful antioxidant, and it seems that plays a crucial role in prevention of some disease $[15,16]$. It has been proven that Cellular Oxidant Stress (COS) plays an important role in pathogenesis of cancers. Based on mitochondrial model of cancer, some specific mutations in the nuclear and nonnuclear (mitochondrial) genes that encoding components of the electron transport chain can lead to increase in COS generation [17-20]. Some previous studies declared that cancer cells normally produce more COS than do normal cells [17]. Some types of the cells have higher metabolic functions than do other cells and these variances could easily translate into higher rates of mitochondrial stress oxidative factors formation. Epithelial cells of thyroid gland produce amounts of reactive oxygen species (ROS) which are necessary for T3 and T4 hormones synthesis $[21,22]$. Nevertheless, when these cells create excessive ROS caused toxic effects on thyroid cells. Wang and co-workers [23] recommended that any increasing in oxidant parameters is associated with occurrence of thyroid cancer. In an investigation that performed by Muzza et al. [24] has been shown that the intracellular $\mathrm{H}_{2} \mathrm{O}_{2}$ (as oxidant parameters) is significantly higher in PTCs than in normal thyroid tissues [24]. Tabur et al. [25] surveyed the role of 8-OHdG and oxidative stress in PTC. They proposed that impaired antioxidant status plays a crucial role in PTC pathogenesis. Given the key role of ROS in the pathogenesis of PTC and proven antioxidant activity of pumpkin seeds, it seems selection of pumpkin seed in the present study is a precious choice.

Present study showed a significantly higher number of apoptotic bodies in PTC groups that treated with HLPS or PTX compared with the control group. The understanding of apoptosis has provided the fundamental basis for cancer therapies that can induce tumor cell death or sensitize them to chemotherapy radiation therapy. Apoptosis is an important process for development, cellular differentiation, and physiological and non-physiological death [26]. This process is characterized by a complex series of structural and functional changes such as swelling of the cell membrane, cell shrinkage, nuclear condensation and genomic fragmentation [27]. In the recent approach of cancer therapy, some agents target the apoptosis pathway and induce cancerous cell death. Generally, apoptotic cells are detected using a TUNEL assay. Due to the high cost, did not allow the use of TUNEL assay in this study. Therefore we used H\&E and Giemsa stinging for detection of morphological changes including cell shrinkage, membrane blebbing, chromatin condensation, and nuclear fragmentation. In the present investigation, HLPS extract and PTX induced formation of apoptotic bodies in treated cell population, as compared to control group (untreated PTC cells). Our results are in agreement with the results of the study done by Shen et al. [28]. Their results suggested that polysaccharides, which obtained from pumpkin induced apoptosis process and may have potential as a cancer chemotherapeutic agent for the prevention and treatment of hepatocellular carcinoma [28]. 
In the present study, the $\mathrm{IC}_{50}$ value of PTX was significantly less than the $\mathrm{IC}_{50}$ value of hydro-alcoholicextract of HLPS at all of the incubation time. In pharmacological studies, the $\mathrm{IC}_{50}$ is a measure of the effectiveness of a material in inhibiting a particular biological or biochemical function $[29,30]$. The $\mathrm{IC}_{50}$ value of a drug or herbal product can be calculated by creating a dose-response curve and examining the effect of various doses of antagonist on reversing agonist activity. Aforementioned value can be measured for a given antagonist by calculating the concentration needed to inhibit half of the maximum biological response of the agonist. Moreover, these values can be used to compare the effectiveness of the two antagonists. There is a positive relation between calculated $\mathrm{IC}_{50}$ values and conditions under which they are measured. In the cell culture and tissue engineering, lower $\mathrm{IC}_{50}$ represents the higher influence of a compound to inhibit the growth of cells and to cause toxicity and cell death, but the issue is open to discussion.

Present project is the first survey that investigates the effects of HLPS on PTC. In previous studies, therapeutic effects of this plant on breast, blood and prostate cancer has been proven. Richter and co-workers [14] examined the Phytoestrogen Extracts of Pumpkin Seeds on breast cancer. Their findings highlighted a potential role of aforementioned extract in breast cancer prevention and treatment. In another study, Xie [9] surveyed the effects of extracted protein from pumpkin on melanoma, their study showed the inhibitory effects of these proteins on aforementioned cancer proliferation. Moreover, the inhibitory action of pumpkin is also proven on leukemia and prostate cancer.

PTX, a routine chemotherapy drug, was found to prevent the de-polymerization of microtubules, a necessary process of cell division. De-polymerization of Microtubules blocks cells in G2 and M phases of the cell cycle and the result is cell death. Aforementioned effect on cells undertaking mitosis likely explains the selectivity of PTX for proliferating cells over quiescent cells [31, 32]. Because of some adverse side effects of the PTX in patients and invoke drug resistance. The most common side effects of PTX include: anemia, stomach pain, nausea and vomiting and etc. Based on above reasons single targeted aforementioned medications commonly lack efficacy.

In conclusion, as previously mentioned, HLPS hydroalcoholic extract induce cell death in PTC cell lines. Present results could highpoint a potential role of HLPS in PTC prevention or/and treatment. Moreover, it seems accompanying of PTX consumption with HLPS have better therapeutic effects. Albeit for realistic decision about the effect of HLPS on PTC, more molecular investigations are necessary.

\section{ORCID}

Mohammad Hadi Bahadori:

https://orcid.org/0000-0001-9840-0229

Zoleikha Azari: https://orcid.org/0000-0001-5923-0482

Arash Zaminy: https://orcid.org/0000-0002-2388-481X

Sara Dabirian: https://orcid.org/0000-0002-7945-6558

Seyed Mojtaba Mehrdad:

https:/orcid.org/0000-0003-2641-452X

Bahman Jalali Kondori:

https://orcid.org/0000-0002-6134-9965

\section{Author Contributions}

Conceptualization: MHB, BJK. Data acquisition: ZA, AZ. Data analysis or interpretation: ZA. Drafting of the manuscript: ZA, SD. Critical revision of the manuscript: SD, SMM. Approval of the final version of the manuscript: all authors.

\section{Conflicts of Interest}

No potential conflict of interest relevant to this article was reported.

\section{Acknowledgements}

Grant support was provided by Guilan University of Medical Sciences (no. 3/132/8162/P). We would like to thank Cellular and Molecular Research Center at school of Medicine.

\section{References}

1. Halenka M, Fryšák Z. Papillary thyroid carcinoma. In: Halenka M, Fryšák Z, editors. Atlas of Thyroid Ultrasonography. Cham: Springer; 2017. p.165-245.

2. Valderrabano P, Simons S, Montilla-Soler J, Pal T, Zota V, Otto K, McIver B, Coppola D, Leon ME. Medullary thyroid carcinoma. In: Nasir A, Coppola D, editors. Neuroendocrine Tumors: Review of Pathology, Molecular and Therapeutic Advances. New York: Springer; 2016. p.117-40.

3. Ganly I, Ibrahimpasic T, Rivera M, Nixon I, Palmer F, Patel SG, Tuttle RM, Shah JP, Ghossein R. Prognostic implications of papillary thyroid carcinoma with tall-cell features. Thyroid 
2014;24:662-70.

4. Yardley DA. nab-Paclitaxel mechanisms of action and delivery. J Control Release 2013;170:365-72.

5. Apaya MK, Chang MT, Shyur LF. Phytomedicine polypharmacology: cancer therapy through modulating the tumor microenvironment and oxylipin dynamics. Pharmacol Ther 2016;162:58-68.

6. Zubair H, Azim S, Ahmad A, Khan MA, Patel GK, Singh S, Singh AP. Cancer chemoprevention by phytochemicals: nature's healing touch. Molecules 2017;22:395.

7. Caili F, Huan S, Quanhong L. A review on pharmacological activities and utilization technologies of pumpkin. Plant Foods Hum Nutr 2006;61:73-80.

8. Yadav M, Jain S, Tomar R, Prasad GB, Yadav H. Medicinal and biological potential of pumpkin: an updated review. Nutr Res Rev 2010;23:184-90.

9. Xie JM. Induced polarization effect of pumpkin protein on B16 cell. Fujian Med Univ Acta 2004;38:394-5.

10. Cheong NE, Choi YO, Kim WY, Bae IS, Cho MJ, Hwang I, Kim JW, Lee SY. Purification and characterization of an antifungal PR-5 protein from pumpkin leaves. Mol Cells 1997;7:214-9.

11. Xanthopoulou MN, Nomikos T, Fragopoulou E, Antonopoulou S. Antioxidant and lipoxygenase inhibitory activities of pumpkin seed extracts. Food Res Int 2009;42:641-6.

12. Jian L, Du CJ, Lee AH, Binns CW. Do dietary lycopene and other carotenoids protect against prostate cancer? Int J Cancer 2005;113:1010-4.

13. Pan HZ, Qiu XH, Li H, Jin J, Yu C, Zhao J. Effect of pumpkin extracts on tumor growth inhibition in S180-bearing mice. Pract Prev Med 2005;12:745-7.

14. Richter D, Abarzua S, Chrobak M, Vrekoussis T, Weissenbacher T, Kuhn C, Schulze S, Kupka MS, Friese K, Briese V, Piechulla B, Makrigiannakis A, Jeschke U, Dian D. Effects of phytoestrogen extracts isolated from pumpkin seeds on estradiol production and ER/PR expression in breast cancer and trophoblast tumor cells. Nutr Cancer 2013;65:739-45.

15. Medjakovic S, Hobiger S, Ardjomand-Woelkart K, Bucar F, Jungbauer A. Pumpkin seed extract: cell growth inhibition of hyperplastic and cancer cells, independent of steroid hormone receptors. Fitoterapia 2016;110:150-6.

16. Ghosh D, Biswas PK. Enzyme-aided extraction of carotenoids from pumpkin tissues. Indian Chem Eng 2016;58:1-11.

17. Kurfurstova D, Bartkova J, Vrtel R, Mickova A, Burdova A, Majera D, Mistrik M, Kral M, Santer FR, Bouchal J, Bartek J. DNA damage signalling barrier, oxidative stress and treatmentrelevant DNA repair factor alterations during progression of human prostate cancer. Mol Oncol 2016;10:879-94.

18. Poprac P, Jomova K, Simunkova M, Kollar V, Rhodes CJ, Valko M. Targeting free radicals in oxidative stress-related human diseases. Trends Pharmacol Sci 2017;38:592-607.

19. Hecht F, Pessoa CF, Gentile LB, Rosenthal D, Carvalho DP,
Fortunato RS. The role of oxidative stress on breast cancer development and therapy. Tumour Biol 2016;37:4281-91.

20. Gill JG, Piskounova E, Morrison SJ. Cancer, oxidative stress, and metastasis. Cold Spring Harb Symp Quant Biol 2016;81:163-75.

21. Praveen KJ, Deepa M, Julius A, Nadiger HA. Study on thyroid status and oxidants in smokers and alcoholics. J Evol Med Dent Sci 2013;2:6982-7.

22. Asci A, Bulus D, Andiran N, Kocer-Gumusel B. Evaluation of the relation between thyroid dysfunction and oxidant/antioxidant status in obese children. Paper presented at: ESPE 2014; 2014 Sep 18-20; Dublin, Ireland. p. 82.

23. Wang D, Feng JF, Zeng P, Yang YH, Luo J, Yang YW. Total oxidant/antioxidant status in sera of patients with thyroid cancers. Endocr Relat Cancer 2011;18:773-82.

24. Muzza M, Colombo C, Cirello V, Perrino M, Vicentini L, Fugazzola L. Oxidative stress and the subcellular localization of the telomerase reverse transcriptase (TERT) in papillary thyroid cancer. Mol Cell Endocrinol 2016;431:54-61.

25. Tabur S, Aksoy ŞN, Korkmaz H, Ozkaya M, Aksoy N, Akarsu E. Investigation of the role of 8-OHdG and oxidative stress in papillary thyroid carcinoma. Tumour Biol 2015;36:2667-74.

26. Li-Weber M. Targeting apoptosis pathways in cancer by Chinese medicine. Cancer Lett 2013;332:304-12.

27. Saeedi Borujeni MJ, Hami J, Haghir H, Rastin M, Sazegar G. Evaluation of Bax and $\mathrm{Bcl}-2$ proteins expression in the rat hippocampus due to childhood febrile seizure. Iran J Child Neurol 2016;10:53-60.

28. Shen W, Guan Y, Wang J, Hu Y, Tan Q, Song X, Jin Y, Liu Y, Zhang Y. A polysaccharide from pumpkin induces apoptosis of HepG2 cells by activation of mitochondrial pathway. Tumour Biol 2016;37:5239-45.

29. Bento AP, Gaulton A, Hersey A, Bellis LJ, Chambers J, Davies M, Krüger FA, Light Y, Mak L, McGlinchey S, Nowotka M, Papadatos G, Santos R, Overington JP. The ChEMBL bioactivity database: an update. Nucleic Acids Res 2014;42(Database issue):D1083-90.

30. Volpe DA, Hamed SS, Zhang LK. Use of different parameters and equations for calculation of IC50 values in efflux assays: potential sources of variability in IC50 determination. AAPS J 2014;16:172-80.

31. Benbow SJ, Wozniak KM, Kulesh B, Savage A, Slusher BS, Littlefield BA, Jordan MA, Wilson L, Feinstein SC. Microtubuletargeting agents eribulin and paclitaxel differentially affect neuronal cell bodies in chemotherapy-induced peripheral neuropathy. Neurotox Res 2017;32:151-62.

32. Rouzier R, Rajan R, Wagner P, Hess KR, Gold DL, Stec J, Ayers M, Ross JS, Zhang P, Buchholz TA, Kuerer H, Green M, Arun B, Hortobagyi GN, Symmans WF, Pusztai L. Microtubule-associated protein tau: a marker of paclitaxel sensitivity in breast cancer. Proc Natl Acad Sci U S A 2005;102:8315-20. 